\section{Foxl1 is a mesenchymal Modifier of Min in carcinogenesis of stomach and colon}

\author{
Nathalie Perreault, ${ }^{1,4}$ Sara D. Sackett, ${ }^{1,4}$ \\ Jonathan P. Katz, ${ }^{1,2}$ Emma E. Furth, ${ }^{3}$ and \\ Klaus H. Kaestner ${ }^{1,5}$
}

Departments of ${ }^{1}$ Genetics and ${ }^{2}$ Medicine, University of Pennsylvania School of Medicine, Philadelphia, Pennsylvania, 19104-6145, USA; ${ }^{3}$ Department of Pathology and Laboratory Medicine, University of Pennsylvania,

Philadelphia, Pennsylvania 19104-4283, USA

Constitutive activation of the Wnt/APC/ $\beta$-catenin pathway is a frequent initiating event in gastrointestinal carcinogenesis. Mutations in the Adenomatous Polyposis Coli $(A P C)$ gene up-regulate Wnt signaling by stabilizing $\beta$-catenin and causing activation of targets important in proliferation control. Here we show that loss of the mesenchymal transcription factor Foxl1 leads to a marked increase in tumor multiplicity in the colon of $A p c^{\text {Min }}$ mice. $\mathrm{Apc}^{\mathrm{Min} /{ }^{+}}{ }_{\text {Foxl1 }}{ }^{-/-}$mice also develop gastric tumors not observed in $A p c^{\mathrm{Min}}$ mice. These effects are caused by earlier tumor initiation due to accelerated loss of heterozygosity ( $\mathrm{LOH}$ ) at the Apc locus. Foxl1 is the first mesenchymal Modifier of Min and plays a key role in gastrointestinal tumorigenesis.

Received September 10, 2004; revised version accepted December 1, 2004.

Gastric and colorectal cancers are common malignant neoplasms and account for $>1$ million deaths worldwide every year. Constitutive activation of the Wnt/APC/ $\beta$ catenin pathway is an initiating event in colorectal carcinogenesis and is observed in most sporadic and hereditary colorectal cancers as well as in sporadic gastric cancer (Morin 1999; Smith et al. 1999; Pinto et al. 2003). Intrafamilial variation in phenotype contributes significantly to the complexity of familial adenomatous polyposis (FAP), a hereditary form of colorectal cancer. Despite carrying the same mutation in the $A P C$ gene, affected individuals can have dramatic differences in disease expression (Crabtree et al. 2002; Su et al. 2002). Beyond environmental effects or variations in clinical practice, the large phenotypic differences even between same-sex siblings strongly suggest the existence of other genes that modify the tumor risk conferred by a given $A P C$ mutation. The genes responsible for this variable

[Keywords: APC; FAP; FOXL1; LOH; $\beta$-catenin]

${ }^{4}$ These authors have contributed equally to this work.

${ }^{5}$ Corresponding author.

E-MAIL kaestner@mail.med.upenn.edu; FAX (215) 573-5892.

Article published online ahead of print. Article and publication date are at http://www.genesdev.org/cgi/doi/10.1101/gad.1260605. expression of the FAP phenotype are still unknown. However, the search for modifier genes was greatly facilitated by the discovery of a cancer-predisposing mutation in mice, termed Multiple Intestinal Neoplasia, or Min, which was shown to be caused by a point mutation in the mouse ortholog of APC (Moser et al. 1990; Shoemaker et al. 1997). Min mice develop numerous polyps, predominantly in the small intestine, and die by 5 mo of age with anemia and intestinal blockage. Tumor multiplicity was found to be dependent on the inbred strain in which the Min mutation was analyzed and led to the identification of the first modifier gene of the Min/APC phenotype (Dietrich et al. 1993; Gould et al. 1996). This locus, termed Modifier of Min1 (Mom1), contains several candidate genes, including the epithelial phospholipase A2 (PLA2S-II or Pla2g2a gene) (Cormier et al. 1997, 2000). However, thus far no functional variants have been found in the human ortholog of Pla2g2a in FAP patients, suggesting that other genetic loci might act as modifiers of the phenotype observed in FAP (Tomlinson et al. 1996; Nimmrich et al. 1997).

Foxl1 is a winged helix transcription factor expressed in the mesenchyme of the gastrointestinal tract (Kaestner et al. 1996, 1997) and an important regulator of the Wnt/APC/ $\beta$-catenin pathway (Perreault et al. 2001). Mice homozygous for a Foxl1-null mutation demonstrate increased nuclear accumulation of $\beta$-catenin in the epithelia of the stomach and intestine (Perreault et al. 2001). However, Foxl1-null mice do not develop adenomas in their gastrointestinal tract, even at $1 \mathrm{yr}$ of age. As both $A p c$ and Foxl1 influence the accumulation of nuclear $\beta$-catenin, we hypothesized that the absence of Foxll protein in the gut mesenchyme would synergize with the $A p c^{\mathrm{Min}}$ mutation in the gut epithelium in tumor initiation and/or progression. We tested the hypothesis that Foxl1 is a potential Modifier of Min using a genetic approach, and demonstrate that loss of Foxl1 increases tumor multiplicity in $A p c^{\text {Min }}$ mice in a dramatic fashion. This effect is caused by accelerated loss of heterozygosity (LOH) at the $A p c^{\text {Min }}$ locus. These findings underscore the need to consider the contribution of the stroma to the initiation and progression of gastrointestinal adenomas and for additional therapeutic approaches to the treatment of gastrointestinal cancer.

\section{Results and Discussion}

Loss of Foxll increases gastrointestinal tumor load in $\mathrm{APC}^{\text {Min }}$ mice

To evaluate whether Foxl1 is a Modifier of Min, we crossed $A p c^{M i n}$ mice with mice carrying a null mutation in Foxl1 on the defined, inbred C57Bl6 background (Kaestner et al. 1997). We found no polyps in the stom-

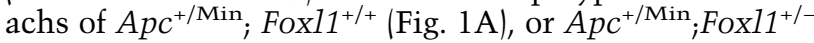
mice (data not shown) followed up to $90 \mathrm{~d}$. However, $\mathrm{Apc}^{+/ \mathrm{Min}}{ }_{\text {; } F o x l 11^{-/-}}$mice developed an average of $5.5 \mathrm{pol}-$ yps in the stomach by 3 mo of age, demonstrating a major impact of Foxl1 on gastric tumor initiation (Fig. 1B,E) $(P<0.002)$. Foxl1 also had a dramatic effect on tumor load in the colon. While $A p c^{+/ M i n}{ }_{;} F_{O X X 11^{+/+}}$and $A p c^{+/ M i n}$; Fox $11^{+/-}$mice (Fig. 1C,F) had an average of 3.2 and 3.7 colonic polyps, respectively, $\mathrm{Apc}^{+/ \mathrm{Min}}{ }_{\text {F Fox } 11^{-/-}}$mice (Fig. 


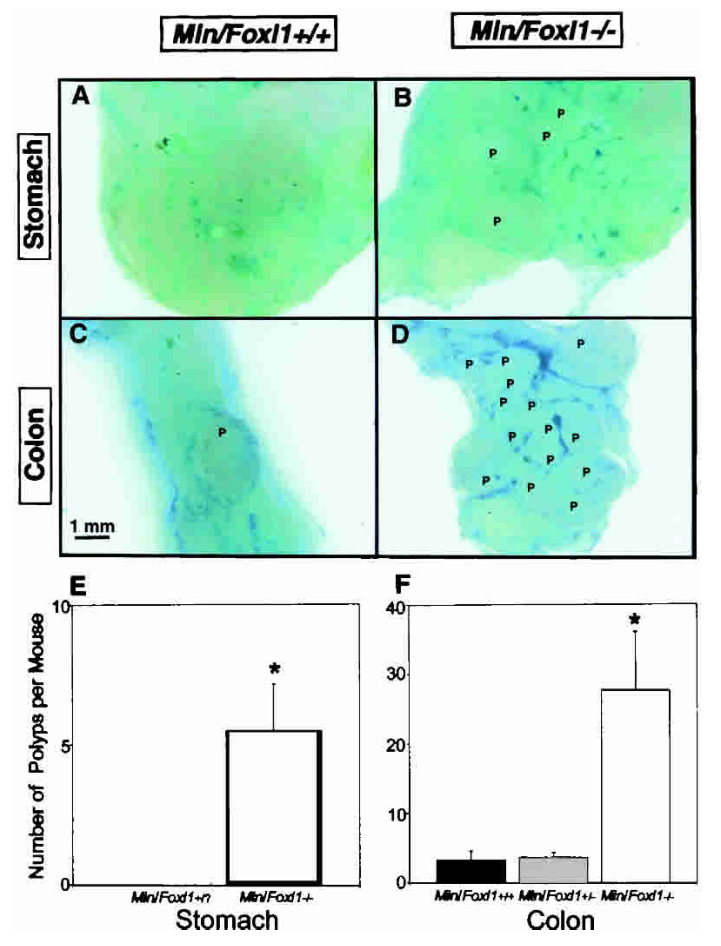

Figure 1. Loss of Foxl1 in $A p c^{M i n}$ mice increases tumor multiplicity. Macroscopic evaluation of stomach $(A, B)$ and colon $(C, D)$ demonstrated increased tumor multiplicity in 70- to 90-d-old Min mice with a homozygous deletion of Foxl1 $(B, D)$. No polyps (labeled as p) were found in the stomach of $A p c^{+/ M i n} / F_{0 x} 11^{+/+}$mice $(A)$ compared with an average of 5.5 polyps in $A p c^{+/ M i n} / F_{0 x} 11^{-/-}$mice $(B)$. Loss of Foxl1 in $\mathrm{Apc}^{+/ \mathrm{Min}}$ mice also had a dramatic effect on tumor number in the colon. $\mathrm{Apc}^{+/ \mathrm{Min}} / \mathrm{Foxl1}^{+/+}$mice $(C)$ had an average of 3.2 colonic polyps compared with an average of 27.8 polyps in $\mathrm{Apc}^{+/ \mathrm{Min}} / \mathrm{Foxl1}^{-/}$ mice $(D)$. Thus, in both the stomach $(E)$ and colon $(F)$, the loss of Foxl1 had a significant effect on tumor multiplicity in $\mathrm{Apc}^{+/ \mathrm{Min}}$ mice $(P<0.002$ for the stomach and $P<0.005$ for the colon by one-way ANOVA; $n=4$ per genotype analyzed).

$1 \mathrm{D}, \mathrm{F})$ developed an average of 27.8 polyps per animal, a 7.7-fold increase over $A p c^{+/ M i n}{ }_{\text {F Fox }} 11^{+/+}$mice (Fig. 1F) $(P<0.005)$. In the small intestine, where $A p c^{\text {Min }}$ mice normally develop $\sim 50$ polyps per mouse (Shoemaker et al. 1997), tumor multiplicity up to $90 \mathrm{~d}$ was not significantly affected by the loss of Foxl1 (data not shown). These results suggest that Foxl1 and Apc act cooperatively to regulate tumor multiplicity in the stomach and colon.

No gastric adenomas were found in the stomachs of $\mathrm{Apc}^{+/ \mathrm{Min}}$;Foxl1 $1^{+/+}$or Foxl1 $1^{-/-}$mice (Fig. 2A,C), consistent with our previous findings that Foxl1 $1^{-/}$mice do not develop tumors even at $1 \mathrm{yr}$ of age (Kaestner et al. 1997).

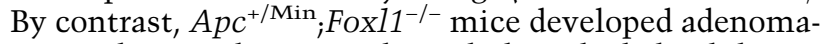
tous polyps in the stomach, with disturbed glandular architecture, increased nuclear to cytoplasmic ratio, and nuclear atypia (Fig. 2E). To confirm that these lesions are truly polyps of proliferating epithelial cells, we performed immunohistochemical staining for proliferating cell nuclear antigen (PCNA). Adenomatous polyps in $A p c^{+/ M i n}{ }_{F}$ Fox $11^{-/-}$mice displayed a high frequency of PCNA-positive epithelial cells (Fig. 2F), in contrast to $\mathrm{Apc}^{+/ \mathrm{Min}}{ }_{;} \mathrm{Foxl1}^{+/+}$, in which proliferating cells are confined to the neck region (Fig. 2B), and Foxl1 ${ }^{-/-}$mice with a more scattered distribution of PCNA-positive cells (Fig. 2C). We also considered the possibility that decreased apoptosis might contribute to the increased

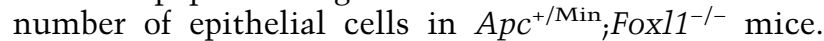
However, there was no change in the rate of apoptosis in $\mathrm{Apc}^{+/ \mathrm{Min}}$;Foxl1 $1^{-/-}$mice compared with controls as determined by TUNEL assay (data not shown). In the colon, $\mathrm{Apc}^{+/ \mathrm{Min}}$;Foxl1 ${ }^{-/-}$mice formed adenomas that were histologically similar to the polyps found in $\mathrm{Apc}^{+/ \mathrm{Min}}$; Fox $11^{+/+}$mice (data not shown). There was no evidence of invasion or metastases in any of the tumors. Thus, loss of Foxl1 promotes gastric and colonic tumorigenesis in the $A p c^{\text {Min }}$ mice, but does not affect tumor grade or stage in either the stomach or the colon up to $90 \mathrm{~d}$ of age.

\section{Foxl1+/+; APCMin}

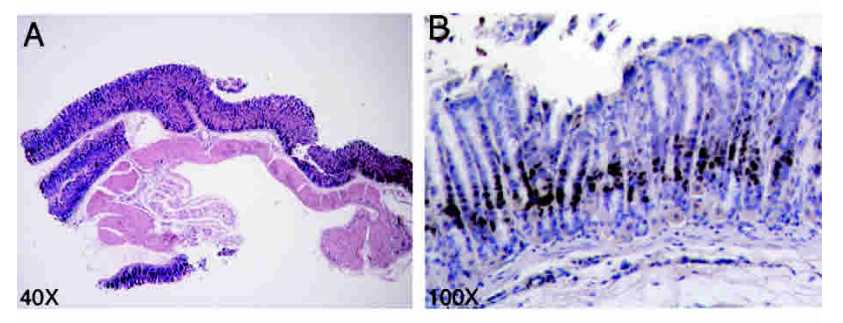

Foxl1-/-

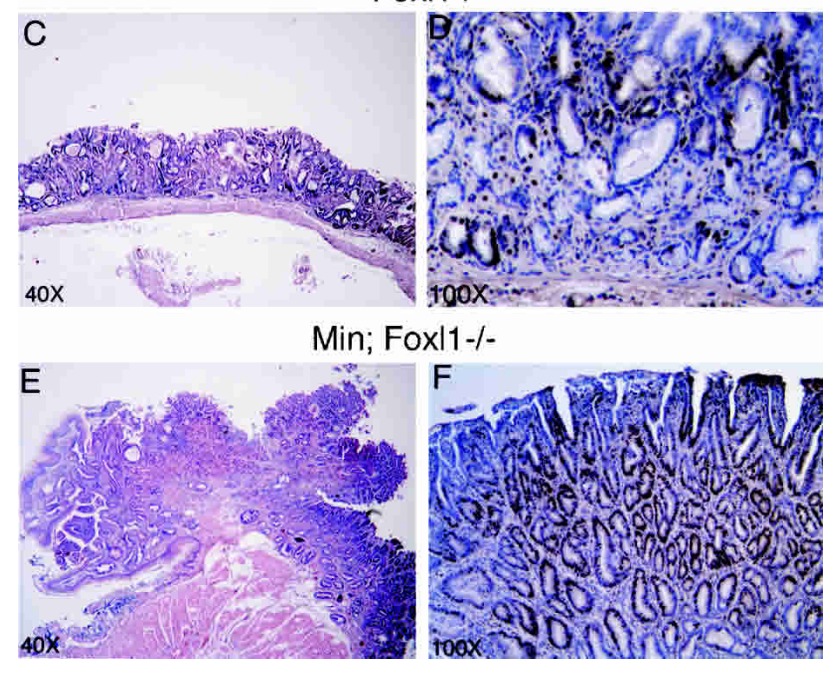

Figure 2. Loss of Foxl1 in $A p c^{+/ M i n}$ mice leads to gastric polyp formation. Histological analyses of the stomach confirmed the presence of gastric tumors in 70- to 90-d-old $\mathrm{Apc}^{+/ \mathrm{Min}} / \mathrm{Foxl1}^{-/-}$animals. Hematoxylin and eosin staining was performed on paraffin sections of stomach from either $A p c^{+/ M i n} / F_{0 x 11^{+/+}}(A)$, Foxl1-/- $(C)$, or $A p c^{+/ M i n} /$ Foxl1 $1^{-/}$animals $(E)$. The gastric mucosa from the $A p c^{+/ M i n} / F_{0 x l 1}{ }^{+/+}$ (A) showed no polyp formation. Although the morphology of the gastric epithelia in the Foxl1 $1^{-1-}$ mice $(C)$ was abnormal with branching of the glands and the presence of mucin filled cysts, no polyps were observed. $A p c^{+/ M i n} / F_{0 x 11^{-1-}}$ mice $(E)$ showed a dramatic induction in polyp formation. Immunohistochemical detection of PCNA shows proliferating cells confined to the neck region of the glandular stomach in $\mathrm{Apc}^{+/ \mathrm{Min}} / \mathrm{Foxl1} 1^{+/+}$mice, scattering of proliferating cells in Foxl1 $1^{-/-}$mice, and a dramatic accumulation of proliferating epithelial cells in the polyps of $A p c^{+/ M i n} /$ Foxl1-1- mice. $(B, D, F)$ Immunohistochemical detection of PCNA. (B) Proliferating cells are confined to the neck region in $A p c^{+/ M i n} /$ Fox $11^{++}$mice. $(D)$ Proliferating cells are spread throughout the epithelium of Foxi1 $1^{-1-}$ mice. $(F)$ Adenomatous polyps in $A p c^{+/ M i n} / F o x 11^{-/-}$mice display a high frequency of proliferating cells. Magnification is indicated on the individual panels. 
Foxll deficiency accelerates tumor initiation in $\mathrm{APC}^{\mathrm{Min}}$ mice

Previous reports have suggested that the majority of polyps in the $A p c^{M i n}$ mouse arise by 3 mo of age (Moser et al. 1990, 1992). At this age, $A p c^{+/ M i n}{ }_{;} F o x 11^{-/-}$mice already developed an increased number of colonic polyps compared with $\mathrm{Apc}^{+/ \mathrm{Min}}{ }_{\text {; Fox }} \mathrm{1}^{+/+}$mice. We therefore hypothesized that loss of Foxl1 affects tumor initiation, not tumor progression. To investigate this notion, we analyzed 30-d-old mice for evidence of early tumor initiation. Colons were removed and embedded in paraffin in a Swiss roll orientation such that their entire length could be evaluated on a single section. The sections were then analyzed and scored for the formation of adenomas (Fig. 3). As expected, no adenomas were found in young $\mathrm{Apc}^{+/ \mathrm{Min}}{ }_{\text {; Foxl1 }} \mathrm{H}^{++}$animals, and their colonic crypts displayed normal architecture and cellular morphology (Fig. 3A,B). In $\mathrm{Apc}^{+/ \mathrm{Min}}$;Foxl1 $1^{-/-}$mice, however, we observed a number of well-developed adenomas at $30 \mathrm{~d}$ of age (Fig. 3D,E). The epithelial cells in these polyps were dysplastic and disordered with nuclear hyperchromasia and atypia (Fig. 3D,E). These adenomas also exhibited increased BrdU labeling, indicative of increased DNA synthesis (Fig. 3F), while in the normal-appearing colon of 30-d-old $\mathrm{Apc}^{+/ \mathrm{Min}}{ }_{\text {; Fox }} \mathrm{H}^{+/+}$mice, cells in S phase are confined to the bottom third of the crypts (Fig. 3C). The increased proliferation rate in adenomas of 30 -d-old
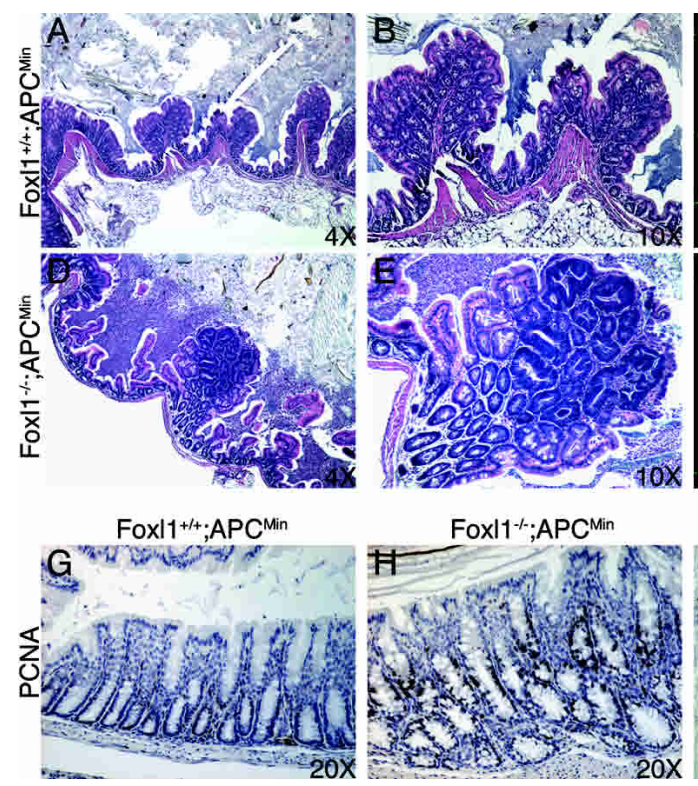

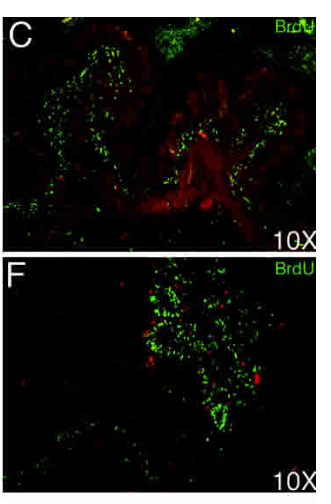

Foxl1 $11^{-1-} ; \mathrm{APC}^{\mathrm{Min}}$

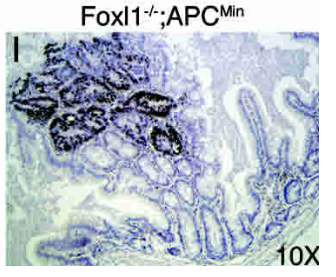

Figure 3. Homozygous deletion of Foxl1 in $A p c^{+/ M i n}$ mice induces early tumor formation. The colons of 30 -d-old mice were removed, embedded in paraffin in a Swiss roll orientation, and scored for the presence of adenomas. No early adenomas were found in $A p c^{+/ M i n} / F o x l 1^{+/+}$mice $(n=4)(A, B)$, and the colonic crypts revealed normal architecture and cell histology. Colonic sections from $A p c^{+/ M i n} / F_{0 x} 11^{-1}$ mice $(n=4)(D, E)$ demonstrated a number of already well-developed adenomas at 30 d. Note the architectural distortion, nuclear hyperchromasia, and atypia. Immunofluorescence for BrdU (green) indicated a significant increase in the number of proliferating cells in the adenomas from the $A p c^{+/ M i n} / F o x l 1^{-1-}$ mice $(F)$ compared with $\mathrm{Apc}^{+/ \mathrm{Min}} / \mathrm{Foxl1}^{+/+}$mice $(C)$. Evan's blue (red) was used as counterstain. PCNA staining of colonic section from 30-d-old mice demonstrates that proliferating cells are confined to the bottom third of the crypts in $A p c^{+/ M i n} /$ Fox $11^{+/+}$mice $(G)$ and the normal appearing mucosa of $A p c^{+/ M i n} /$ Foxl1 $1^{-/-}$mice $(H)$, while a large number of proliferating epithelial cells are found in the adenomas of $A \mathrm{pc}^{+/ \mathrm{Min}} / \mathrm{Fox} 11^{-/-}$mice $(I)$. Magnification is indicated on the individual panels.

$\mathrm{Apc}^{+/ \mathrm{Min}}{ }_{;} \mathrm{Fox}_{\mathrm{I}} \mathrm{1}^{-/-}$mice was also confirmed by PCNA The loss of the wild-type Apc allele in $\mathrm{Apc}^{\mathrm{Min}}$ mice Next, we investigated the molecular mechanism by which the mesenchymal factor Foxl1 impacts on the Hnt/APC/ $\beta$-catenin pathway to accelerate tumor initiaion. We previously established that loss of Foxl1 alone eads to augmented nuclear localization of $\beta$-catenin by mown the amount of heparan sulfate proteoglycans, lar matrix (Perreault et al. 2001). Therefore, we considered the possibility that enhanced signaling via the Wnt/ APC/ $\beta$-catenin pathway caused by the $A p c^{\text {Min }}$ mutation, ith the increased Wnt signaling operative in

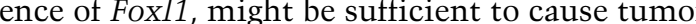
$\mathrm{Apc}^{+}$allele. However when we determined $\beta$-catenin levels in the stomach and colon of 30-d-old mice of all relevant genotypes, we found these not sigificantly different between Fox $11^{-/-}$and $A p c^{+/ M i n}$ Foxl1 and Apc mutations described above is not the sult of passing the threshold of nuclear $\beta$-catenin required for tumorigenesis. Therefore, we investigated whether the loss of the second, wild-type $A p c$ allele might be accelerated in the absence of Foxl1. $\mathrm{LOH}$ is thought to be a stochastic event that is dependent on the age of the individual or, more specifically, the number of times the genome undergoes replication. To determine whether LOH had occurred, we isolated small numbers of cells from either normal colonic mucosa or adenomas (only present in $A p c^{+/ M i n}$; Foxl1 ${ }^{-/-}$mice) (Fig. 3) from 30-d-old mice by laser capture microdissection. LOH at the $A p c$ locus can be analyzed by taking advantage of a restriction fragment length polymorphism (Yamada et al. 2002). As shown in Figure 4B, in 30-d-old $\mathrm{Apc}^{+/ \mathrm{Min}}$; Foxl1 ${ }^{+/+}$, which lack adenomas, no LOH was observed, consistent with previous findings (Yamada et al. 2002). In contrast, 30-d-old $A p c^{+/ M i n}{ }_{;}$Foxl1 $1^{-/-}$mice have lost the wild-type $A p c$ allele in their polyps, demonstrating that $\mathrm{LOH}$ is accelerated in absence of Foxl1, providing a molecular explanation for the increased tumor load in these mice (Fig. 4B). We developed a quantitative PCR assay based on the single nucleotide polymorphism in the $A p c$ gene that differentiates the wild type from the $A p c^{\text {Min }}$ allele. Using this assay, we demonstrate that the wild-type allele is reduced by $>90 \%$ in adenomas from 70 d-old $\mathrm{Apc}^{+/ \mathrm{Min}}$ mice (Fig. 4C,E) as well as in 30-d-old $A p c^{+/ M_{i n}}$;Fox $11^{-/-}$mice (Fig. 4D,F). Thus, LOH at the Apc locus is clearly accelerated in the absence of Foxl1. We propose that due to the higher turnover of the epithelial cell caused by loss of Foxl1 (Perreault et al. 2001), epithelial stem cells or their descendants have undergone three to four times the number of $S$ phases than a Fox $11^{+/+}$mouse by 1 mo of age, increasing the likelihood of somatic recombination at the Apc locus and thus LOH by the 


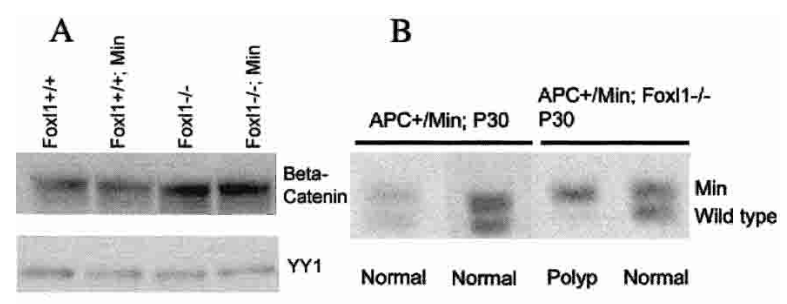

C

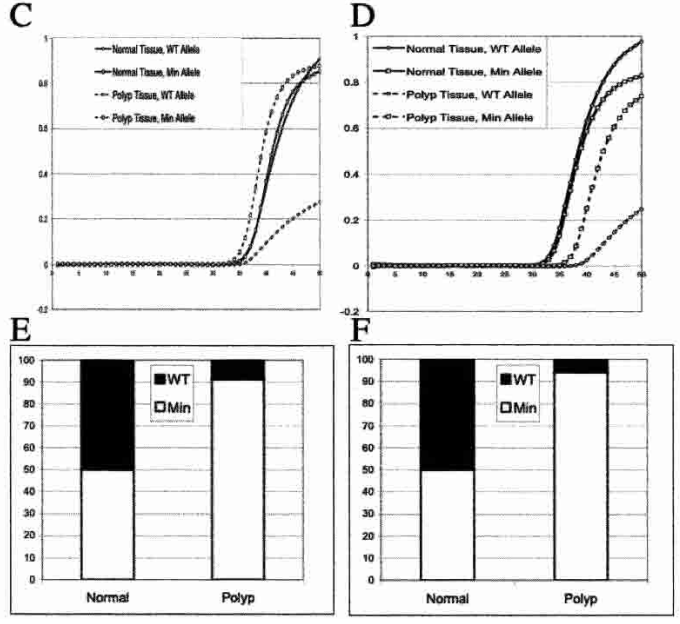

Figure 4. Loss of Foxl1 in $\mathrm{Apc}^{+/ \mathrm{Min}}$ mice accelerates loss of heterozygosity (LOH) at the Apc locus. (A) Western blot analysis of nuclear extracts from colons of 30 -d-old mice indicates that while there is a two- to threefold increase in nuclear $\beta$-catenin caused by the loss of Foxl1, no further increase is seen when one $A p c^{M i n}$ allele is present. $(B)$ $\mathrm{LOH}$ analysis by conventional PCR. PCR amplification produces a 123-bp band for the wild type and an 144-bp product for the $A p c^{+/ \text {Min }}$ allele. LOH is indicated by the absence of the wild-type band. In 30-dold $\mathrm{Apc}^{+/ \mathrm{Min}} / \mathrm{Foxl1}^{+/+}$mice, which have only normal appearing mucosa, no LOH has occurred. In contrast, adenomas in $\mathrm{Apc}^{+/ \mathrm{Min}} / \mathrm{Foxl1}^{-1-}$ mice show $\mathrm{LOH}$ already at $30 \mathrm{~d}$ of age. $(C-F)$ Real-time quantitative PCR analysis for LOH at the Apc locus. (C) A polyp form a 70-d-old $\mathrm{Apc}^{+/ \mathrm{Min}} / \mathrm{Foxl}^{+/+}$mouse shows loss of the wild-type Apc allele, while in the adjacent normal tissue both wild-type and ApcMin alleles are present at equal frequencies. (D) A polyp from a 30-d-old $A p c^{+/ \text {Min } /}$ Foxl1 ${ }^{-/-}$mouse shows loss of the wild-type Apc allele similar to the situation in $C .(E, F)$ Quantification of the allele frequencies obtained in $C$ and $D$, respectively, demonstrating that $\mathrm{LOH}$ occurs in tumors of 30-d-old $\mathrm{Apc}^{+/ \mathrm{Min}} / \mathrm{Foxl1}^{-/-}$mice $(F)$ to the same degree as in 70 -d-old $A p c^{+/ \text {Min }} /$ Foxl1 $1^{+/+}$mice $(E)$.

same magnitude. This increased rate of recombination then results in the earlier onset of adenoma formation in Fox $11^{-1-}$; $A p c^{\text {Min }}$ mice. We hypothesize that other genes, or even environmental conditions, that favor increased turnover of gastrointestinal epithelial cells will likewise accelerate tumor formation in $A p c^{\mathrm{Min}}$ mice or FAP patients. In summary, we have identified Foxl1 as an important regulator of the $W n t / \beta$-catenin pathway and the first mesenchymal Modifier of Min.

\section{Materials and methods}

Mice

C57BL/6J- $A p c^{\mathrm{Min}}$ mice were obtained from Jackson Laboratory. For studies of early tumor initiation, $\mathrm{Apc}^{+/ \mathrm{Min}_{i}}$ Fox $\mathrm{Fl}^{+/+}$, and $\mathrm{Apc}^{+/ \mathrm{Min}}$ Foxl1 ${ }^{-/-}$ mice on a C57BL/6J background were sacrificed at $30 \mathrm{~d}$ of age. For other

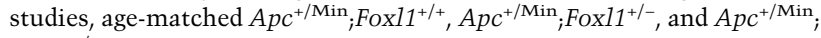
Fox11 ${ }^{-1-}$ mice on a C57BL/6J background were sacrificed between 70 and $90 \mathrm{~d}$ of age. Mice were genotyped for $A p c^{\mathrm{Min}}$ and Foxl1 alleles as reported previously (Dietrich et al. 1993; Kaestner et al. 1997).
Histology

Tissues were fixed in $4 \%$ paraformaldehyde overnight at $4^{\circ} \mathrm{C}$, embedded in paraffin, cut to $5-\mu \mathrm{m}$ sections, and applied to Probe-on Plus slides (Fisher Scientific). Tissues were incubated after rehydration in Hematoxylin for $2.5 \mathrm{~min}$, rinsed in water, dipped quickly in $0.5 \%$ acid alcohol, and washed in water. Tissues were then immersed in $0.2 \% \mathrm{NaHCO}_{3}$, rinsed in water, dipped in eosin for $15 \mathrm{sec}$, and briefly rinsed in water before dehydration and mounting.

\section{Quantification of micro- and macroadenomas}

To evaluate macroademomas in adult mice, the gastrointestinal tract from stomach to rectum was removed en bloc. The small intestine was cut into thirds, and the stomach, cecum, and colon were separated. Segments were cut longitudinally and washed gently with PBS to remove fecal material. Tissues were placed in a petri dish, and the mucosa was overlaid with $1 \%$ methylene blue. A dissection microscope was used to count the polyps. For quantification of macroademomas in 30-d-old mice, the entire colon was removed, fixed in $4 \%$ paraformaldehyde overnight, and embedded in paraffin in Swiss roll orientation such that the entire length of the colon could be identified on a single section. Fivemicron sections were stained with Hematoxylin and eosin as described above. The sections were then analyzed and scored for presence of adenomas.

\section{Proliferation and apoptosis assays}

Mice were injected intraperitoneally with $10 \mathrm{~mL} / \mathrm{kg}$ BrdU reagent (ZYMED) 90 min prior to sacrifice. For immunofluorescence, tissues were fixed, sectioned, and processed as described above. Slides were subjected to microwave antigen retrieval by boiling for $6 \mathrm{~min}$ in $10 \mathrm{mM}$ citric acid buffer (pH 6.0). Slides were washed in PBS and blocked with protein blocking reagent (Immunotech) for $20 \mathrm{~min}$ at room temperature. Mouse monoclonal anti-BrdU (1:500, Roche) was diluted in PBS containing $0.1 \%$ BSA and $0.2 \%$ Triton X-100 (PBT) and incubated with the sections overnight at $4{ }^{\circ} \mathrm{C}$. Slides were washed in PBS, followed by incubation with FITC-conjugated goat anti-mouse antibody (1:25, Roche), diluted in PBT, for $2 \mathrm{~h}$ at room temperature. Slides were washed in PBS, counterstained in $0.01 \%$ Evan's blue solution for $20 \mathrm{sec}$, rinsed in PBS, mounted with Vectashield (Vector), and examined using confocal fluorescence microscopy. For PCNA immunohistochemistry, endogenous peroxidases were quenched by treating slides in $1.5 \%$ hydrogen peroxide for $15 \mathrm{~min}$. Tissues were blocked with Avidin D and Biotin blocking reagents for $15 \mathrm{~min}$ each, followed by blocking in $1.5 \%$ normal goat serum. Slides were probed with anti-PCNA (1:9000, mouse monoclonal, DAKO). Sections were washed three times for $10 \mathrm{~min}$ in $1 \times$ PBS and incubated with biotinylated anti-mouse secondary for $30 \mathrm{~min}$ at room temperature. Sections were washed three times for $10 \mathrm{~min}$ in $1 \times$ PBS, followed by incubation with HRP-conjugated $\mathrm{ABC}$ reagent from Vecta Elite Kit (Vector) for $30 \mathrm{~min}$ at room temperature. The signal was developed using DAB Substrate Kit (Vector).

Apoptosis was analyzed using the in situ cell death detection kit-AP (Roche Molecular Biochemicals). Fifty microliters of TUNEL reaction mixture were added to the samples and incubated in a humidified chamber for $1 \mathrm{~h}$ at $37^{\circ} \mathrm{C}$. Following washes in $1 \times \mathrm{PBS}$, slides were incubated with anti-fluorescin antibody-AP (Roche) for $30 \mathrm{~min}$ at $37^{\circ} \mathrm{C}$. The signal was developed using NBT $(100 \mathrm{mg} / \mathrm{mL})$ and BCIP $(50 \mathrm{mg} / \mathrm{mL})$ (Boehringer) for 2-5 min. Positive cells were identified by blue nuclear staining.

\section{Western blot analysis}

The amounts of $\beta$-catenin and YY1 as loading control in nuclear extracts from colon of 30-d-old mice was determined as described previously (Perreault et al. 2001).

\section{Allelic loss analysis (LOH studies)}

Fox $11^{+/+} ; A p c^{+/ \text {Min }}$, Fox $11^{+/-} ; A p c^{+/ \text {Min }}$, and Foxl1 ${ }^{-/-} ; \mathrm{Apc}^{+/ \text {Min }}$ mice on a $\mathrm{C} 57 \mathrm{BL} / 6 \mathrm{~J}$ background were sacrificed at 30 and $70 \mathrm{~d}$ of age. To identify areas of dysplasia, the stomach and colons were removed, the colons opened longitudinally, and fixed in $4 \%$ paraformaldehyde overnight at $4^{\circ} \mathrm{C}$ overnight, embedded in paraffin, cut into 5 - $\mu \mathrm{m}$ sections, applied to membrane slides for laser-microdissection (Molecular Machines and Industries), and examined by using an en face preparation. To identify areas of dysplasia, slides were stained in Hematoxylin and eosin. For each 
genotype, 21-28 serial sections were used to locate the intramucosal lesions.

Areas of dysplastic tissues and adjacent normal tissue were captured using the SLMCut (Molecular Machines and Industries). Samples were collected on microfuge caps with diffuser and glue (Molecular Machines and Industries). The samples were removed from the cap with $25 \mu \mathrm{L}$ of $1 \times$ PCR buffer with Proteinase K (Qiagen) and incubated overnight at $56^{\circ} \mathrm{C}$. After inactivation of Proteinase $\mathrm{K}$ by heating to $95^{\circ} \mathrm{C}$ for $10 \mathrm{~min}$, the samples were subjected to conventional PCR analysis and SNP analysis.

For LOH of the Apc gene via conventional PCR, DNA was amplified using forward (5'-TCTCGTTCTGAGAAAGACAGAAGCT-3') and reverse $\left(5^{\prime}\right.$-TGATACTTCTTCCAAAGCTTTGGCTAT-3 $\left.{ }^{\prime}\right)$ primers (Yamada et al. 2002). The underlined base pairs differ from the $A p c$ coding sequences in order to generate a HindIII restriction site. After PCR, DNA products were digested with HindIII and separated by electrophoresis on a $2.5 \%$ agarose gel and stained with SYBRgreen.

For real-time PCR TaqMan SNP (small nucleotide polymorphism) analysis, PCR primers, flanking the $A p c^{\text {Min }}$ point mutation, were designed as follows: sense, primer 5'-AGTTTAGACAGTTCTCGTTCT GAGAAAG-3'; and antisense, 5'-ATGGTAAGCACTGAGGCCAA TAC-3'. Dual-labeled probes were designed using the following criteria: length between 13 and 20 nucleotides, estimated $\mathrm{Tm}$ between $65^{\circ} \mathrm{C}$ and $67^{\circ} \mathrm{C}$, no guanine residue at the $5^{\prime}$ end of the probe, and the position of the polymorphism in the central third. The TaqMan probes were designed complementary to the antisense genomic DNA, spanning the point mutation, as follows: wild type, 5'-6FAM-TCTCTCCAAACTTC -BHQ1-3'; mutant, 5'-JOE-CTCTCTCCTAACTTC-BHQ2-3'. The Allele Discrimination SNP Real-time PCR conditions were initial denaturation for $10 \mathrm{~min}$ at $95^{\circ} \mathrm{C}$ followed by 50 cycles of $95^{\circ} \mathrm{C}$ for $30 \mathrm{sec}$ and $58^{\circ} \mathrm{C}$ for 1 min. The Allelic Discrimination SNP Real-time analysis was performed using a Stratagene Mx4000.

\section{Acknowledgments}

We are grateful to Drs. Anil Rustgi, Debra Silberg, Linda Greenbaum, and Greg Enders for critical reading of the manuscript. Our studies were facilitated by the Center for Molecular Studies in Digestive and Liver Disease at the University of Pennsylvania. This work was supported by grants from the NIH and the Natural Sciences and Engineering Research Council of Canada.

\section{References}

Cormier, R.T., Hong, K.H., Halberg, R.B., Hawkins, T.L., Richardson, P., Mulherkar, R., Dove, W.F., and Lander, E.S. 1997. Secretory phospholipase Pla2g2a confers resistance to intestinal tumorigenesis. Nat. Genet. 17: 88-91.

Cormier, R.T., Bilger, A., Lillich, A.J., Halberg, R.B., Hong, K.H., Gould, K.A., Borenstein, N., Lander, E.S., and Dove, W.F. 2000. The Mom1AKR intestinal tumor resistance region consists of Pla2g2a and a locus distal to D4Mit64. Oncogene 19: 3182-3192.

Crabtree, M.D., Tomlinson, I.P., Hodgson, S.V., Neale, K., Phillips, R.K., and Houlston, R.S. 2002. Explaining variation in familial adenomatous polyposis: Relationship between genotype and phenotype and evidence for modifier genes. Gut 51: 420-423.

Dietrich, W.F., Lander, E.S., Smith, J.S., Moser, A.R., Gould, K.A., Luongo, C., Borenstein, N., and Dove, W. 1993. Genetic identification of Mom-1, a major modifier locus affecting Min-induced intestinal neoplasia in the mouse. Cell 75: 631-639.

Gould, K.A., Dietrich, W.F., Borenstein, N., Lander, E.S., and Dove, W.F. 1996. Mom 1 is a semi-dominant modifier of intestinal adenoma size and multiplicity in Min/+ mice. Genetics 144: 1769-1776.

Kaestner, K.H., Bleckmann, S.C., Monaghan, A.P., Schlondorff, J., Mincheva, A., Lichter, P., and Schutz, G. 1996. Clustered arrangement of winged helix genes fkh-6 and MFH-1: Possible implications for mesoderm development. Development 122: 1751-1758.

Kaestner, K.H., Silberg, D.G., Traber, P.G., and Schutz, G. 1997. The mesenchymal winged helix transcription factor Fkh6 is required for the control of gastrointestinal proliferation and differentiation. Genes \& Dev. 11: 1583-1595.

Morin, P.J. 1999. $\beta$-Catenin signaling and cancer. Bioessays 21: 10211030.

Moser, A.R., Pitot, H.C., and Dove, W.F. 1990. A dominant mutation that predisposes to multiple intestinal neoplasia in the mouse. Science 247: 322-324.

Moser, A.R., Dove, W.F., Roth, K.A., and Gordon, J.I. 1992. The Min (multiple intestinal neoplasia) mutation: Its effect on gut epithelial cell differentiation and interaction with a modifier system. J. Cell. Biol. 116: 1517-1526.

Nimmrich, I., Friedl, W., Kruse, R., Pietsch, S., Hentsch, S., Deuter, R., Winde, G., and Muller. O. 1997. Loss of the PLA2G2A gene in a sporadic colorectal tumor of a patient with a PLA2G2A germline mutation and absence of PLA2G2A germline alterations in patients with FAP. Hum. Genet. 100: 345-349.

Perreault, N., Katz, J.P., Sackett, S.D., and Kaestner, K.H. 2001. Foxl1 controls the Wnt $/ \beta$-catenin pathway by modulating the expression of proteoglycans in the gut. J. Biol. Chem. 276: 43328-43333.

Pinto, D., Gregorieff, A., Begthel, H., and Clevers, H. 2003. Canonical Wnt signals are essential for homeostasis of the intestinal epithelium. Genes \& Dev. 17: 1709-1713.

Shoemaker, A.R., Gould, K.A., Luongo, C., Moser, A.R., and Dove, W.F. 1997. Studies of neoplasia in the Min mouse. Biochim. Biophys. Acta 1332: F25-F48.

Smith, K., Bui, T.D., Poulsom, R., Kaklamanis, L., Williams, G., and Harris, A.L. 1999. Up-regulation of macrophage wnt gene expression in adenoma-carcinoma progression of human colorectal cancer. Br. J. Cancer 81: 496-502.

Su, L.K., Kohlmann, W., Ward, P.A., and Lynch, P.M. 2002. Different familial adenomatous polyposis phenotypes resulting from deletions of the entire APC exon 15. Hum. Genet. 111: 88-95.

Tomlinson, I.P., Neale, K., Talbot, I.C., Spigelman, A.D., Williams, C.B., Phillips, R.K., and Bodmer, W.F. 1996. A modifying locus for familial adenomatous polyposis may be present on chromosome 1p35-p36. J. Med. Genet. 33: 268-273.

Yamada, Y., Hata, K., Hirose, Y., Hara, A., Sugie, S., Kuno, T., Yoshimi, N., Tanaka, T., and Mori, H. 2002. Microadenomatous lesions involving loss of Apc heterozygosity in the colon of adult Apc(Min/+) mice. Cancer Res. 62: 6367-6370. 


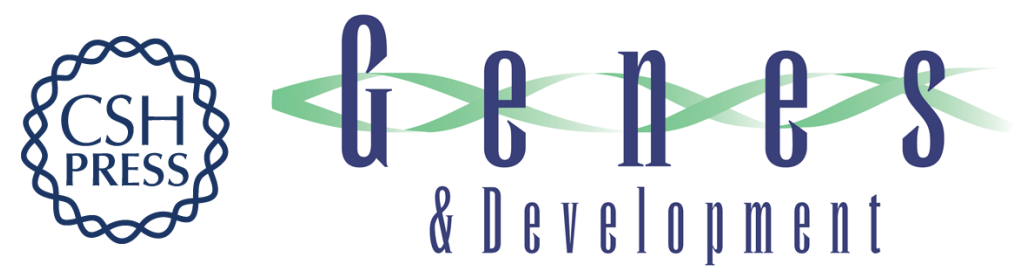

\title{
Foxl1 is a mesenchymal Modifier of Min in carcinogenesis of stomach and colon
}

\author{
Nathalie Perreault, Sara D. Sackett, Jonathan P. Katz, et al.
}

Genes Dev. 2005, 19:

Access the most recent version at doi:10.1101/gad.1260605

\section{Related Content Trans-Cellular Genetic Modification in Cancer \\ Sci. STKE February, 2005 2005: tw53}

References This article cites 18 articles, 10 of which can be accessed free at: http://genesdev.cshlp.org/content/19/3/311.full.html\#ref-list-1

Articles cited in:

http://genesdev.cshlp.org/content/19/3/311.full.htmI\#related-urls

\section{License}

Email Alerting

Receive free email alerts when new articles cite this article - sign up in the box at the top Service right corner of the article or click here.

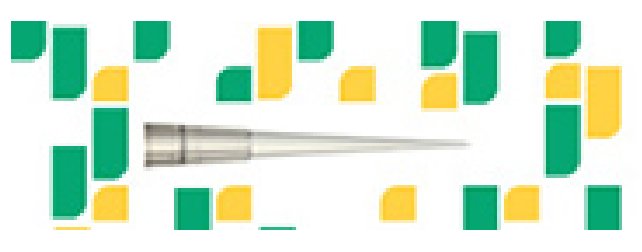

Focused on your science. 